\title{
Heterotrophic nanoflagellate enhancement of bacterial growth through nutrient remineralization in chemostat culture
}

\author{
Karen E. Selph*, Michael R. Landry, Edward A. Laws \\ Department of Oceanography, University of Hawaii at Manoa, 1000 Pope Road, Honolulu, Hawaii 96822, USA
}

\begin{abstract}
Heterotrophic nanoflagellates are the principal consumers of picoplankton in the ocean. Their role as nutrient remineralizers is also well established. However, the coupled interactions between grazer consumption and prey growth are less well understood. In this work, we demonstrate a tight coupling among flagellate grazing, nitrogen remineralization, and prey growth, resulting in bacterial growth rates averaging 2- to 14 -fold higher in the presence of flagellate grazers. These results were obtained using 2-stage, nitrogen-limited chemostats containing a mixed culture of heterotrophic bacteria enriched from seawater and Paraphysomonas bandaiensis, a chrysomonad flagellate. Abundance and biovolume of the flagellates were monitored on a daily basis, as was bacterial abundance. Grazing rates were measured using short-term tracer uptake experiments (fluorescently-labeled bacteria and beads), and these data were used to calculate gross bacterial growth rates in the presence of grazers. A mass balance approach was used to estimate reduced nitrogen regenerated by the protist and nitrogen demand of the heterotrophic bacteria. These independent methods of assessing grazer growth and feeding, coupled with estimates of flagellate gross growth efficiency, provided strong, internally consistent constraints on the estimates of bacterial growth rates in the presence of grazers. Under these culture conditions, $P$. bandaiensis had a carbon-based gross growth efficiency averaging $28 \%$. This work shows that independently measured grazing rates are essential in protist culture work if system dynamics are to be understood. It also underscores the necessity of including protist remineralization pathways in models if realistic simulations are to be obtained.
\end{abstract}

KEY WORDS: Nanoflagellate grazing - Bacterial growth rates · Nutrient remineralization . Chemostats $\cdot$ Flow cytometry $\cdot$ FLB $\cdot$ Gross growth efficiency

\section{INTRODUCTION}

Marine microbial food webs are characterized by organisms with high growth potentials (i.e. $>1 \mathrm{~d}^{-1}$ ) and relatively short reaction times to environmental change (Fenchel 1987). Thus, we tend to view these systems as closely-coupled consortia with complex interactions that maintain component populations in a state of dynamic equilibrium (Fogg 1986, Calbet \& Landry 1999, Landry \& Kirchman 2002). In the open ocean, growth of microbes, including auto- and heterotrophic bacteria, is generally limited by reduced carbon substrates or mineral nutrients (e.g. Thingstad 1987, Landry et al. 1997, Rivkin \& Anderson 1997, Karl
1999). Similarly, food availability constrains the growth of their primary consumers, heterotrophic nanoflagellates (Landry \& Kirchman 2002), which also function as major nutrient remineralizers (Goldman et al. 1985, Caron et al. 1990, Eccleston-Parry \& Leadbeater 1995). The latter is enhanced by the fact that bacterivorous nanoflagellates consume prey with nutrient:carbon contents (e.g. N:C ratio of 1:4 for bacteria) higher than needed for growth $(<1: 5)$, and therefore excrete the excess (e.g. Caron et al. 1990, Landry 1993, Elser \& Urabe 1999). Rapid grazing and efficient remineralization of the limiting resource $(\mathrm{N}, \mathrm{P}$, or Fe) are therefore essential for sustaining rapid growth rates at the base of open ocean food webs (Landry et al. 1997). 
Controlled laboratory experiments with simplified food webs are useful for beginning to understand the interactions and feedbacks in microbial systems. Chemostats are particularly suited to the study of coupled processes in such systems, as the primary substrate levels can be controlled, along with growth rates of the cultured members. Previous studies, for instance, have utilized chemostat approaches to study grazing effects on prey populations (Andersson et al. 1986, Pernthaler et al. 1997, Šimek et al. 1997, Hahn \& Hofle 1998), nutrient remineralization (Güde 1985, Pengerud et al. 1987, Sambanis \& Fredrickson 1987, Hagström et al. 1988, Jürgens \& Güde 1990, Hoch et al. 1996), and prey concentration effects on predator growth rates (Parslow et al. 1986, Eccleston-Parry \& Leadbeater 1994b). Some investigators have explicity accounted for prey growth in the presence of grazers (Habte \& Alexander 1978, Güde 1985, Sambanis \& Fredrickson 1987, Šimek et al. 1997), but more typically, chemostat studies of predator-prey relations have made the assumption of no prey growth in the presence of grazers, and thus have calculated grazing impacts consistent with that assumption (e.g. Hamiliton \& Preslan 1970, Curds \& Cockburn 1971, Jost et al. 1973, Ashby 1976, Swift et al. 1982, Jürgens \& Güde 1990).

In the present study, heterotrophic bacteria were grown in the presence and absence of nanoflagellate consumers in 2-stage, nitrogen-limited chemostats to investigate the coupled processes of growth, grazing and nutrient remineralization within a simple microbial food chain. This culture system was chosen in order to regulate the growth rate of the populations, as well as control temperature and medium replenishment rate. Thus, variations in grazing and nutrient remineralization rate could be better constrained and explained. As this predator-prey system oscillated around equilibrium levels, the limiting nutrient (reduced nitrogen) was conserved by rapid bacterial uptake and efficient cycling through the flagellate predators. Tight coupling of these processes substantially enhanced growth rates of prey in the presence of grazers, a factor that is often poorly accounted for in chemostat studies.

\section{MATERIALS AND METHODS}

Experimental design and monitoring. Experiments were conducted in 2-stage continuous cultures under similar conditions of medium type, temperature $\left(18^{\circ} \mathrm{C}\right)$ and dilution rate $\left(0.54\right.$ to $\left.0.60 \mathrm{~d}^{-1}\right)$. Three grazing experiments (Expts 1 to 3 ) were conducted for 23, 16 and $7 \mathrm{~d}$, respectively, with outflow from the first stage vessel with prey fed directly and continuously to a second stage containing flagellate predators. Each stage of the chemostat had approximately the same volume and hence the same dilution rate, within $10 \%$. In addition, a $6 \mathrm{~d}$ control experiment was performed under the same culture configuration except that predators were not present in the second stage chemostat. Experiments were ended if there was evidence of contamination, hence the varying duration of each experiment. Dilution rates were determined by measuring the volume of the overflow on a daily basis, in conjunction with the known vessel media volumes (each $~ 11$ ). Dayto-day variations in flow rates were between 2 and $10 \%$. Thus, an overall dilution rate was calculated at the end of the experiment and applied to the population rates-of-change for both stages of the chemostat.

In each experiment, the first-stage chemostat contained a mixed community of heterotrophic bacteria enriched from seawater freshly collected in Mamala Bay, Honolulu, Hawaii. Four separate collections were made, one for each experiment. The bacterial assemblage was obtained by filtering $500 \mathrm{ml}$ of seawater twice through a $2.0 \mu \mathrm{m} / 0.6 \mu \mathrm{m}$ pore size sandwich filter to remove eukaryotes and adding sterile enrichment medium $(500 \mathrm{ml})$ to the filtrate. The enrichment medium was composed of $0.11 \mathrm{mM}$ dextrose, $0.01 \mathrm{~g} \mathrm{l}^{-1}$ casamino acids (\#0230-15-5, Difco), $3.6 \mu \mathrm{M} \mathrm{NaH}{ }_{2} \mathrm{PO}_{4}$ $\mathrm{H}_{2} \mathrm{O}$, and $10 \%$ of the trace metals and vitamins of f-medium (Guillard \& Ryther 1962) in $0.2 \mu \mathrm{m}$ filtered, autoclaved seawater. This medium had a molar C:N:P ratio of 154:11:1 and was presumed to be limited by nitrogen since the molar N:P ratio of natural heterotrophic bacteria has been found to be close to or higher than 10:1 (e.g. Fagerbakke et al. 1996, Cotner et al. 1997, Kuipers et al. 2000).

The first stage culture was stirred in a dark, $18^{\circ} \mathrm{C}$ water bath. After $24 \mathrm{~h}, 400 \mathrm{ml}$ of an exponentially growing culture of the chrysomonad flagellate, Paraphysomonas bandaiensis (provided by D. Caron, University of Southern California), was transferred from a rice-grain batch culture to the second stage vessel. At this time, chemostat flow was started from the first stage to the second stage vessel at a rate of $500 \mathrm{ml} \mathrm{d}^{-1}$. This second vessel containing grazers was maintained as a fed-batch culture for $24 \mathrm{~h}$ before starting the overflow, which was defined as experimental time 0 . The delays in overflow were designed to allow the organisms time to adapt to the new medium, minimizing the likelihood of culture wash-out.

All populations were monitored, starting at time 0 , with samples analyzed by flow cytometry (Monger \& Landry 1993). Flow cytometry analyses typically have a precision of 2 to $5 \%$. Data were gathered in listmode files from Hoechst 33342-stained cells using the properties of right angle light scatter (RALS), forward angle light scatter (FALS) and blue fluorescence (DNA). The resulting files were processed using CytoPC (Vaulot 
1989). The flagellates formed a distinct population, easily separable from the bacteria (Fig. 1).

Biovolumes and biomass. Bacterial cell biovolumes were determined throughout the control experiment and grazing Expt 3. Subsamples were preserved with glutaraldehyde $(1 \%, \mathrm{w} / \mathrm{v}$, final concentration), stained with acridine orange $(0.01 \%, w / v$, final concentration) for $2 \mathrm{~min}$, then gently vacuum-filtered onto $0.2 \mu \mathrm{m}$ black, $25 \mathrm{~mm}$ Poretics filters backed by $0.45 \mu \mathrm{m}$ MSI filters. Filters were rinsed with filtered seawater, then mounted on slides between immersion oil and a cover slip, and frozen $\left(-20^{\circ} \mathrm{C}\right)$ until analysis. Slides were viewed at a magnification of $1650 \times$ using a Zeiss epifluorescence microscope with a $100 \mathrm{~W}$ mercury vapor lamp and a blue excitation filter (450 to 490 band pass, FT 510 beam splitter and LP 520 barrier). Fields were scanned with a C-mounted Sony CCD camera and recorded on VHS VCR tape. Freeze-frame video images were captured using Power Macintosh Video Player 7.5.3 software (v. 1.3.2, Apple Computer), and 30 bacteria per image were measured using the ruler and line tools in Canvas software (v. 3.5.1, Deneba Systems). Cell biovolumes were calculated from the lengths $(L)$ and widths $(W)$ of the mostly rod-shaped bacteria as: Biovolume $=\pi \times\left[\left(W^{2} L / 4\right)-\left(W^{3} / 12\right)\right]$ (Børsheim \& Bratbak 1987).

The equivalent spherical diameter and abundance of live flagellates were estimated daily in $0.5 \mathrm{ml}$ subsamples analyzed with an Elzone/Celloscope model 80XY particle counter with a $64 \mu \mathrm{m}$ orifice tube. The machine was calibrated using $5.2 \mu \mathrm{m}$ polystyrene beads, and the error of measuring the flagellate diameter was $\pm 0.2 \mu \mathrm{m}$. The biovolumecarbon conversion factor and the carbon:nitrogen (C:N) ratio of Paraphysomonas bandaiensis were determined in triplicate, 11 batch cultures in which the flagellates were fed heterotrophic bacteria grown in barley-grain amended filtered seawater. Flagellate abundance and size were monitored using the Elzone particle counter, and the cells were harvested during exponential growth phase $\left(\sim 10^{5}\right.$ flagellates $\mathrm{ml}^{-1}$ ). The bulk of each culture was filtered through a combusted GF/F filter, rinsed with isotonic ammonium formate, then dried at $60^{\circ} \mathrm{C}$ until analysis with a CN Elemental Analyzer (Perkin Elmer Model 2400).

Microscopical inspection of culture and filtrate showed that $5.6 \pm 0.02 \%$ of the bacterial cells passed through the filter resulting in the retention of $>90 \%$ of the bacterial cells on the GF/F. The biomass contributed by these bacteria was estimated by determining the average biovolume of these cells ( $\mathrm{n}$ =94) microscopically, converting that value to carbon

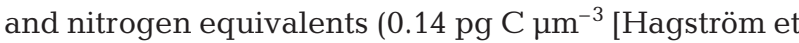
al. 1988], and C:N [w:w] = 4), then multiplying by the number of bacterial cells retained on the GF/F. The estimated bacterial contribution was $8 \pm 2 \%$ of the carbon on the GF/F filter and was subtracted to compute the flagellate biovolume conversion factor. In order to determine a biovolume conversion factor for preserved flagellates, aliquots of the culture were also fixed with glutaraldehyde, filtered, and mounted on slides. Mean flagellate biovolumes were determined microscopically (as described for the bacteria above).

Growth rate calculations. In a chemostat at steady state, there is no change in growth rate over time. Specific growth rates $(\mu)$ of bacteria and flagellates were calculated in daily increments from the dilution rate of the chemostat in conjunction with the abundance data. The growth of the bacteria in the first stage and the flagellates in the second stage can be simply calculated with the following equation, where the observed change in cells over the time interval is equal to the instrinsic growth minus the loss of cells through dilution (Eq. 1):

$$
\frac{\mathrm{d} B_{\mathrm{n}}}{\mathrm{d} t}=\mu_{\mathrm{n}} B_{\mathrm{n}}-D B_{\mathrm{n}}
$$

where: $B_{\mathrm{n}}=$ cells $\mathrm{ml}^{-1}$ in Stage 1 or $2(\mathrm{n}=1$ or 2$)$; $\mu_{\mathrm{n}}=$ specific growth rate in Stage 1 or $2(\mathrm{n}=1$ or 2$)$; $D=$ dilution rate (flow rate of medium through the chemostat per day).

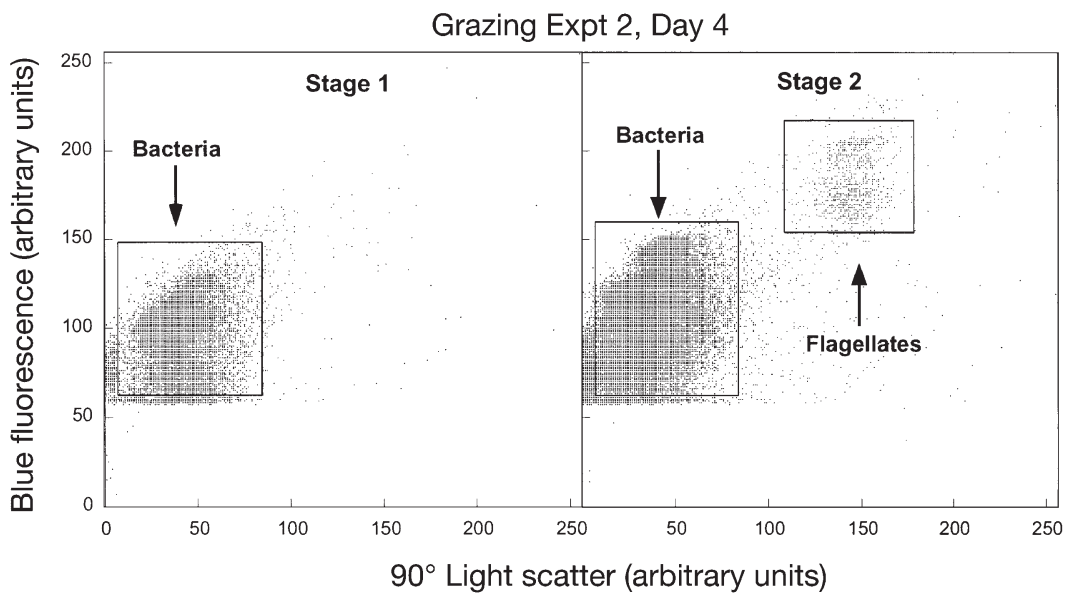

Fig. 1. Example cytograms of flow cytometry data from grazing Expt 2, Day 4. Plotted is blue fluorescence (a proxy for cellular DNA content) as a function of $90^{\circ}$ light scatter (related to cell size and granularity). The Stage 1 sample from the chemostat (left) shows the heterotrophic bacteria in the sample, and the Stage 2 sample (right) shows the heterotrophic bacteria and the flagellate populations. These data are based on a $100 \mu$ sample, diluted 1/100 (Stage 1) or 1/20

(Stage 2) in filtered seawater 
In the second stage, the observed change in numbers of bacteria is due to their instrinsic growth rate, losses due to dilution and grazing, and additions due to supply from the first stage chemostat. Eq. (2) describes this relationship:

$$
\frac{\mathrm{d} B_{\mathrm{n}}}{\mathrm{d} t}=\mu_{2} B_{2}-g B_{2}-D B_{2}+D B_{1}
$$

where $g=$ specific mortality rate due to predators.

Grazing mortality rate $(g)$ was zero in the control experiment without flagellates. At time $t$, Eq. (1) reduces to the logarithmic growth equation, where the exponent is growth minus dilution (Eq. 3). Since we know the dilution rate, the unknown growth rate can be calculated simply by substitution:

$$
B_{\mathrm{n}, t}=B_{\mathrm{n}, 0} \mathrm{e}^{\left(\mu_{\mathrm{n}}-D\right) t}
$$

Solving Eq. (2) for the net bacterial growth rate, $k_{2}$ $\left(=\mu_{2}-g\right)$ in the second stage is somewhat more complex, given that 4 variables affect the change in bacterial abundance over time. The solution to Eq. (2) depends upon whether $B_{1}$ is constant or not. In the present study, we did not assume Stage 1 was at steady state because of the observed fluctuations in bacterial abundance over the course of the experiment. Therefore, the solution to Eq. (2) is:

$$
B_{2, t}=B_{2,0} \mathrm{e}^{\left(\mu_{2}-g-D\right) t}+D \mathrm{e}^{\left(\mu_{2}-g-D\right) t} \int_{0}^{t} B_{1} \mathrm{e}^{-\left(\mu_{2}-g-D\right) t} \mathrm{~d} t
$$

Upon integration and substitution of Eq. (3) for $B_{1(t)}$ and $w=\mu_{1}-D$, Eq. (4) becomes:

$$
B_{2, t}=B_{2,0} \mathrm{e}^{\left(\mu_{2}-g-D\right) t}+\frac{D B_{1,0} \mathrm{e}^{\left(\mu_{2}-g-D\right) t}}{\left(w+D-\mu_{2}+g\right)}\left(\mathrm{e}^{\left(w+D-\mu_{2}+g\right) t}\right.
$$

Given known $D, w, B_{2, t}, B_{2,0}$ and $B_{1,0}$, we solved the equation for net bacterial growth rate, $k_{2}$. We did this by iteration, looking for the minimum difference between observed bacterial abundance at time $t$ and the calculated bacterial abundance at time $t$ using a range of exponents for the value $\left(\mu_{2}-g-D_{2}\right) \times t$. From known $D_{2}$ and $t$, the value that matches best is $y=$ $\left(\mu_{2}-g-\right.$ known $\left.D_{2}\right) \times$ known $t$. To calculate $\mu_{2}$, the $g$ was estimated as the clearance rate of individual flagellates (volume cleared flagellate $\mathrm{e}^{-1} \mathrm{~d}^{-1}$ ) multiplied by the flagellate density (cells volume ${ }^{-1}$ ) (see next section).

Grazing rate estimates. Several short-term feeding experiments were conducted during the first 2 grazing experiments (Expts 1 and 2) based on the uptake of fluorescently labeled bacteria (FLB) or fluorescent polystyrene beads. FLB were made by fluorescently staining heat-killed Pseudomonas diminuta (ATCC\#19146) grown in batch culture (FLB diameter $=0.8$ to $1.0 \mu \mathrm{m}$ ) according to the DTAF (dichlorotriazinyl aminofluorescein) staining method (Sherr et al. 1987). The fluores- cent beads $(0.46 \mu \mathrm{m}$ yellow-green fluorescent polystyrene IDC spheres, CML, Polysciences) were prepared by diluting the beads in filtered seawater and then filtering the suspension through a $3 \mu \mathrm{m}$ filter to remove clumps, followed by sonication. The final concentration was determined flow cytometrically and the appropriate volume added to the flagellate culture (average $2 \%$ of the total prey concentration). Uptake rates were measured by counting the number of fluorescent prey ingested by $P$. bandaiensis in time-course incubations lasting up to $60 \mathrm{~min}$. Each subsample was treated with $\mathrm{NiCl}_{2}(1 \%$, w/v, final concentration), followed by paraformaldehyde $(1 \%$, w/v, final concentration) and then frozen in liquid nitrogen until analysis using dual beam flow cytometry (Monger \& Landry 1992).

Because the uptake experiments were conducted after the flagellates had achieved a relatively constant cell biovolume, these experiments defined the clearance rates within a relatively narrow range of predator and prey sizes. In order to extrapolate to the day-today variations observed in the chemostats, we scaled the uptake experiment results according to the theoretical predictions of Monger \& Landry (1990) for the influences of hydrodynamic and physical-chemical forces on encounter frequencies at the scale of flagellates and bacteria. Monger \& Landry's (1990) work shows that the specific clearance rate is proportional to $R^{-2.4}$ and $r^{0.9}$, where $R$ is the radius of the predator and $r$ is the radius of the prey. This model's predictions have been tested in laboratory cultures, using nanoflagellate protists feeding on bacteria, including the flagellate isolate used in this work (Monger \& Landry 1991, 1992). Since experimental results matched model predictions, this approach to scaling our culture results appears justified. Further, we assumed that the flagellate did not adjust its clearance rate to changes in prey concentration, since its growth rate was well below the maximum achievable by comparably-sized flagellates at a similar temperature ( $<1 \mathrm{~d}^{-1}$ vs $4 \mathrm{~d}^{-1}$, Fenchel 1987). Therefore, daily specific clearance rates $\left(\mathrm{d}^{-1}\right)$ were computed as:

$$
\overline{\mathrm{spF}}=\mathrm{spF} \times\left(\frac{R}{\bar{R}}\right)^{-2.4} \times\left(\frac{r}{\bar{r}}\right)^{0.9}
$$

where $\mathrm{spF}, R$ and $r$ are daily estimates of specific clearance rate, flagellate cell radius $(\mu \mathrm{m})$ and bacterial equivalent spherical radius $(\mu \mathrm{m})$ from the chemostats, respectively, $\overline{\mathrm{spF}}$ and, $\bar{R}$ and $\bar{r}$ are corresponding mean estimates from the FLB uptake experiments. The specific clearance rates were converted to clearance rates $(F)$ using measured flagellate biovolumes.

Given individual flagellate clearance rates $(F), g$ $\left(\mathrm{d}^{-1}\right)$ and ingestion rates $\left(I_{i}\right.$ bacteria flagellate $\left.{ }^{-1} \mathrm{~d}^{-1}\right)$ of flagellates were calculated as: 


$$
\begin{gathered}
g=F \times \bar{A} \\
I=(g \times \bar{B}) / \bar{A}
\end{gathered}
$$

where $\bar{A}$ and $\bar{B}$ are, respectively, the daily averaged concentrations of flagellates and bacteria (cells ml-1) calculated according to Frost (1972):

$$
\bar{A}=\left(A_{t}-A_{0}\right) / \ln \left(A_{t} / A_{0}\right)
$$

Ingestion rates were converted to carbon consumed per unit time $\left(B_{\mathrm{Ct} t} \mu \mathrm{g} \mathrm{C} \mathrm{ml}^{-1} \mathrm{~d}^{-1}\right)$ using $\bar{A}$ and a mean bacterial carbon estimate of $26 \mathrm{fg} \mathrm{C} \mathrm{cell}^{-1}$ (see 'Results: Biomass estimates'). Flagellate abundances were converted to carbon $\left(A_{\mathrm{C}}, \mu \mathrm{g} \mathrm{C} \mathrm{ml}{ }^{-1}\right)$ based on daily biovolume measurements and the mean carbon:biovolume estimate of $0.13 \mathrm{pg} \mathrm{C} \mathrm{mm}^{-3}$ from combusted cultures (see 'Results: Biomass estimates'). A C:N ratio of 5.2 $(\mathrm{w}: \mathrm{w})$ was determined from $\mathrm{CN}$ analyses of flagellate cultures, and we assumed C:N $=4$ for heterotrophic bacteria (Lee \& Fuhrman 1987).

From specific growth rates of flagellates $\left(\mu_{\mathrm{f}}\right)$ calculated according to Eq. (3), we determined flagellate biomass produced per unit time, in terms of carbon and

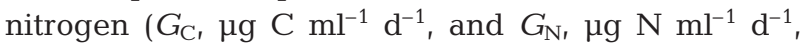
respectively) as:

$$
G_{\mathrm{C}}=\mu_{\mathrm{f}} \times\left(\frac{A_{\mathrm{C}(t)}-A_{\mathrm{C}(0)}}{\ln \left(\frac{A_{\mathrm{C}(t)}}{A_{\mathrm{C}(0)}}\right)}\right)
$$

and

$$
G_{\mathrm{N}}=G_{\mathrm{C}} / 5.2
$$

Carbon-based gross growth efficiency $\left(\mathrm{GGE}_{\mathrm{C}}\right)$ was calculated as the ratio of grazer biomass produced:prey biomass consumed (i.e. $G_{\mathrm{C}}: B_{\mathrm{C}}$ ).

The gross growth rates of Stage 2 bacteria $\left(\mu_{2}\right)$ were estimated from $g$ (Eq. 7) and $k_{2}$ (Eq. 5) as: $\mu_{2}=k_{2}+g$. The ratio of gross growth rates $\left(\mu_{2}: \mu_{1}\right)$ in Stage 1 and 2 chemostats was used as an index of the growth enhancement due to nutrient recycling by flagellate grazers. To determine whether the Stage 2 growth rate enhancement reflected a reasonable balance of supply and demand, we first computed the nitrogen regeneration rate by flagellates as the difference between observed flagellate growth rates and nitrogen-based prey uptake rates. The difference was assumed to be the regenerated nitrogen available to support the bacterial growth inferred for the second stage chemostat. To estimate bacterial demand for regenerated nitrogen, the product of growth rate $\left(\mu_{2}\right)$ and average bacterial abundance in the second stage $\left(\bar{B}_{2}\right)$ was converted to nitrogen equivalents (6 fg $\mathrm{N}$ bacteria $\left.^{-1}\right)$.

\section{RESULTS}

\section{Biomass estimates}

Bacterial abundance increased in the Stage 1 vessels for the first 5 to $6 \mathrm{~d}$ (Fig. 2). The control experiment had a slightly higher rate of increase, but the overall magnitude was similar to that in the grazing experiments. After the first week, bacterial abundance in the grazing experiments displayed an oscillatory pattern (Fig. 2). The initial abundance oscillation had a period of approximately $10 \mathrm{~d}$, while subsequent oscillations were shorter (5 to $6 \mathrm{~d}$ ) and of decreased amplitude.

Unlike Stage 1, Stage 2 of the control experiment (no grazer present) was quite distinct from the grazing experiments, with 2 to 5 times as many bacteria (Fig. 2). No trend is shown for the Stage 2 control data because the Day 4 samples were anomalously low, perhaps because of the lack of preservative or a faulty dilution during flow cytometric analysis. However, abundance generally increased with time.

Bacterial abundance in the grazer-containing Stage 2 vessel initially showed a slight decrease, but within $1 \mathrm{~d}$ the abundance either reached a plateau (Expts 2 and 3 ) or increased (Expt 1, Fig. 2). After the first $6 \mathrm{~d}$ in the grazing experiments, Stage 2 bacterial abundances varied

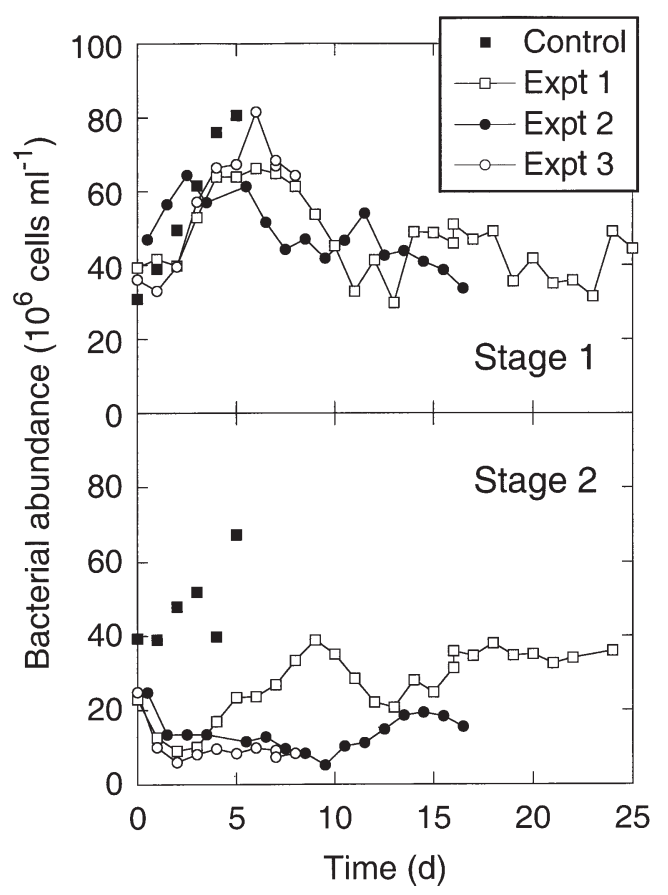

Fig. 2. Bacterial abundance $\left(10^{6}\right.$ cells $\left.\mathrm{ml}^{-1}\right)$ as a function of time (d) in each of the chemostat experiments. Control: control experiment without grazers. Expt 1, Expt 2 and Expt 3 refer to grazing experiments. Stage 1 results are shown in the top panel, Stage 2 results in the bottom panel 
from dramatic increases to small oscillations. Compared with Stage 1, the initial oscillations in abundance were delayed by 5 to $6 \mathrm{~d}$, then had a period of 8 to $10 \mathrm{~d}$.

Bacterial carbon equivalents were calculated using the median biovolume data. In the control experiment, the median biovolumes in Stages 1 and 2 were 0.19 and $0.17 \mu^{3}$, respectively ( $\mathrm{n}=150$ for both estimates). In Expt 3, the median Stage 1 biovolume was $0.24 \mu^{3}$ $(n=210)$, whereas in Stage 2 it was $0.18 \mu^{3}(n=194)$. Combining these estimates yields a range of 24 to $34 \mathrm{fg} \mathrm{C}$ bacteria $^{-1}$ and an overall median of $26 \mathrm{fg} \mathrm{C}$ bacteria $^{-1}$ when using the conversion factor of $0.14 \mathrm{pg} \mathrm{C}$ $\mu \mathrm{m}^{-3}$ (Hagström et al. 1988). Because the bacterial populations underwent changes in right angle light scatter and blue fluroescence as recorded by flow cytometry over the course of the chemostat experiments (data not shown), the use of the median value for bacterial biovolume leads to only approximate estimates of bacterial biomass. However, the biovolume data collected did cover the range of the scatter and

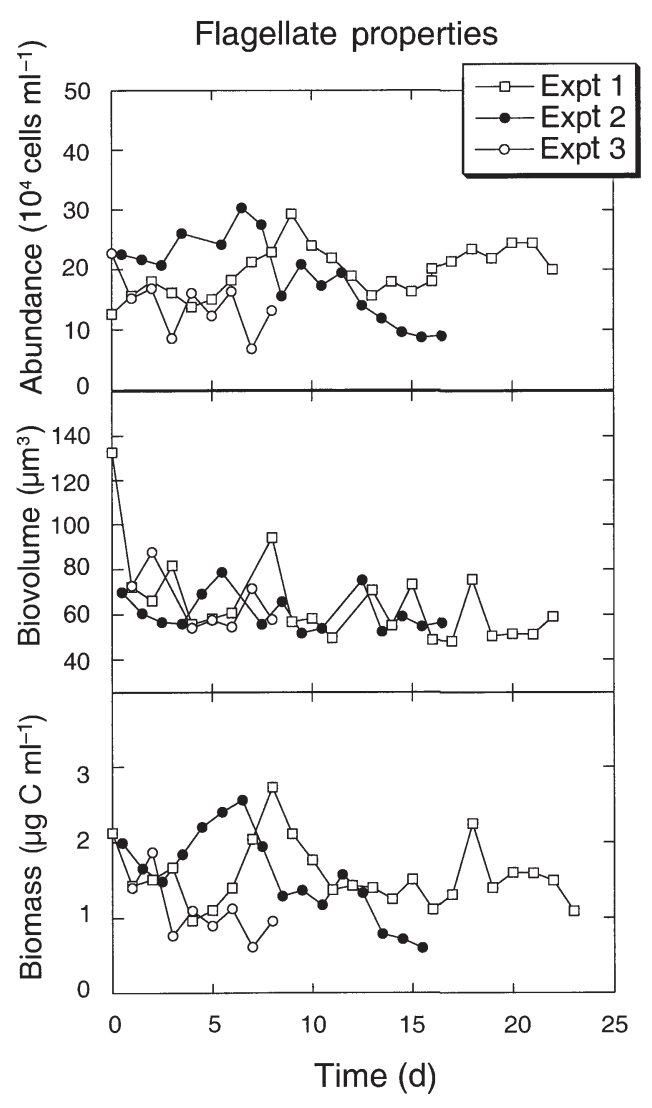

Fig. 3. Paraphysomonas bandaiensis. Abundance, biovolume, and biomass as measured over time in grazing Expts 1 to 3 . Abundance was estimated flow cytometrically, while biovolume was estimated with an Elzone particle counter. Flagellate biomass was calculated using abundance and biovolume

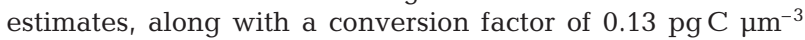
(determined experimentally in this work) blue fluorescence signals recorded by the flow cytometer, so the median value is considered to be an appropriate estimate for all of the experiments.

In order to calculate flagellate biomass, both abundance and biovolume need to be known because flagellate biovolumes can change several-fold depending upon growth and feeding conditions (e.g. Fenchel 1982a). In the present experiments, flagellate biovolumes (based on equivalent spherical diameter) were initially large $\left(>70 \mathrm{\mu m}^{3}\right)$, decreasing rapidly to 50-60 $\mu^{3}$ (Fig. 3). Flagellate abundances were initially similar in all experiments, between 1 and $2.5 \times$ $10^{5}$ cells $\mathrm{ml}^{-1}$, but greater differences became apparent as the experiments progressed (Fig. 3). Oscillations in flagellate abundance characterized the first $2 \mathrm{wk}$ in culture. For the longest experiment (Expt 1), steady state seemed to be approached at $\sim 2.5 \times 10^{5}$ cells ml$^{-1}$.

The carbon-biovolume conversion factor for Para-

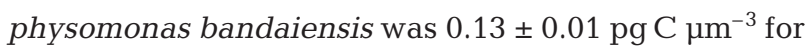
unpreserved cells, as measured by the Elzone particle

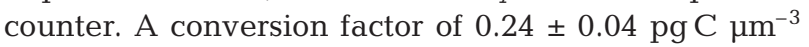
was determined for preserved flagellates. The mean $\mathrm{C}: \mathrm{N}$ ratio $(\mathrm{w}: \mathrm{w})$ for flagellates was $5.2 \pm 0.2$.

Because the average biovolume of the flagellates in Expt 1 was larger than in the other experiments, their initial biomass was similar to Expt 2 flagellates, which had slightly more cells of intermediate size (Fig. 3). By Day 1, however, all experiments had a similar flagellate biomass $\left(1.75 \mu \mathrm{g} \mathrm{C} \mathrm{ml} \mathrm{m}^{-1}\right)$. Flagellates in Expt 2 increased to $2.5 \mu \mathrm{g} \mathrm{C} \mathrm{ml} \mathrm{m}^{-1}$ by Day 6, while those in Expts 1 and 3 declined to their lowest levels $(1.25 \mu \mathrm{g} \mathrm{C}$ $\mathrm{ml}^{-1}$ ). Expt 3 flagellates showed a daily oscillation in biomass, which was still pronounced after $7 \mathrm{~d}$ in culture. Flagellate biomass decreased during the second week of Expt 2, largely reflecting the decline in abundance (Fig. 3). Expt 1 showed an increase in biomass after Day 5, following a relatively short perturbation when the culture operated in batch mode for $8 \mathrm{~h}$. Biomass ultimately decreased to quasi-steady state at approximately $1.5 \mu \mathrm{g} \mathrm{C} \mathrm{ml} \mathrm{m}^{-1}$, only interrupted for a short period on Day 17.

\section{Grazing and mortality rate estimates}

Clearance rate estimates from short-term FLB uptake experiments ranged from 29 to $78 \mathrm{nl}$ flagellate $^{-1} \mathrm{~d}^{-1}$, with a geometric mean of $48 \mathrm{nl}$ flagellate ${ }^{-1}$ $\mathrm{d}^{-1}(\mathrm{n}=9$, Table 1$)$. The average flagellate equivalent spherical diameter was $4.61 \pm 0.08 \mu \mathrm{m}(\mathrm{n}=11)$, with the exception of one measurement where the flagellate was significantly larger $(5.71 \mu \mathrm{m})$. Ingestion rates in these experiments were 430 to 1920 bacteria flagellate $\mathrm{d}^{-1}$, well within the range of published rates for this flagellate and others of similar size and feeding 
Table 1. Paraphysomonas bandaiensis. Direct grazing rate estimates in Expts 1 and 2, calculated from short-term fluorescently labelled bacteria (FLB) or $0.5 \mu \mathrm{m}$ polystyrene-bead uptake experiments (see 'Materials and Methods' section for details). Clearance, ingestion and mortality rates are based on FLB uptake, unless noted with an asterik $\left({ }^{*}\right)$, which indicates that rates are based on bead uptake rates. Flagellate diameter $(\mu \mathrm{m})$ refers to equivalent spherical diameter as measured by the Elzone particle counter on the days that the experiments were conducted

\begin{tabular}{|ccccc|}
\hline $\begin{array}{c}\text { Expt } \\
\text { Days }\end{array}$ & $\begin{array}{c}\text { Flagellate } \\
\text { diameter } \\
(\mu \mathrm{m})\end{array}$ & $\begin{array}{c}\text { Clearance rate } \\
\left(\times 10^{-5} \mathrm{ml} \mathrm{flag}^{-1} \mathrm{~d}^{-1}\right)\end{array}$ & $\begin{array}{c}\text { Ingestion rate } \\
\left(\text { bact flag }^{-1} \mathrm{~d}^{-1}\right)\end{array}$ & $\begin{array}{c}\text { Specific mortality } \\
\text { rate }\left(\mathrm{d}^{-1}\right)\end{array}$ \\
\hline 1 & & & & \\
8 & 5.71 & 4.0 & 1150 & 8.8 \\
9 & 4.70 & 5.4 & 1320 & 12.4 \\
10 & 4.65 & 6.3 & 1300 & 13.9 \\
11 & 4.67 & 5.8 & 940 & 12.7 \\
19 & 4.67 & 2.9 & 960 & 5.5 \\
20 & 4.62 & 5.5 & 1920 & 13.1 \\
21 & 4.57 & 3.2 & 960 & 5.4 \\
2 & & & & \\
8 & 4.69 & 7.8 & 430 & $6.4^{*}$ \\
10 & 4.51 & $3.7^{*}$ & $380^{*}$ & 3.4 \\
13 & 4.51 & 4.8 & 820 & $2.0^{*}$ \\
16 & 4.51 & $2.2^{*}$ & $340^{*}$ & \\
16 & 4.51 & $2.1^{*}$ & $340^{*}$ & \\
\hline
\end{tabular}

$\mathrm{d}^{-1}$, with the variability largely reflecting day-to-day differences in flagellate abundance. In Expt 1 , the specific mortality rates averaged $7.0 \mathrm{~d}^{-1}$, whereas in Expt 3 they were $4.6 \mathrm{~d}^{-1}$. In Expt 2, the overall specific mortality rate was $6.5 \mathrm{~d}^{-1}$, with higher mortality rates over the first $7 \mathrm{~d}$ of the experiment $\left(8.7 \mathrm{~d}^{-1}\right)$, decreasing to $3.1 \mathrm{~d}^{-1}$ on Day 15 .

\section{Growth rates}

Bacterial growth rates based on Stage 1 cell abundances in the control chemostat averaged $0.73 \mathrm{~d}^{-1}$, slightly higher than the dilution rate of $0.54 \mathrm{~d}^{-1}$. The growth rate in the second stage vessel was $0.31 \mathrm{~d}^{-1}$ overall, approximately half that in the first stage. However, when abun-

mode (Berninger et al. 1991, Monger \& Landry 1991, 1992, Eccleston-Parry \& Leadbeater 1994a). Specific mortality rates calculated from the FLB experiments ranged from 3 to $14 \mathrm{~d}^{-1}$, with a geometric mean of $8.8 \mathrm{~d}^{-1}$.

Clearance rates from bead uptake experiments ranged from 21 to $37 \mathrm{nl}$ flagellate $\mathrm{d}^{-1} \mathrm{~d}^{-1}$, with a geometric mean of $26 \mathrm{nl}$ flagellate ${ }^{-1} \mathrm{~d}^{-1}(\mathrm{n}=3$, Table 1$)$. The factor-of-2 difference between clearance rate estimates for the FLB (mean size $=1 \mu \mathrm{m})$ and bead $(0.5 \mu \mathrm{m})$ experiments is consistent with the predicted sizedependency of direct interception feeding by bacterivorous flagellates (Monger \& Landry 1990). Hence, we used these predictions (Eq. 6) to scale for the size variations in bacteria (intermediate between FLB and $0.5 \mu \mathrm{m}$ beads) and flagellates in the Stage 2 chemostats. The resulting clearance rate estimates ranged from 29 to $54 \mathrm{nl}$ flagellate ${ }^{-1} \mathrm{~d}^{-1}$. If the first day of Expt 1, with quite large flagellates, is omitted, then the range of clearance rates was considerably narrower, from 29 to $46 \mathrm{nl}$ flagellate ${ }^{-1} \mathrm{~d}^{-1}$, with each individual experiment having a geometric mean of $36 \mathrm{nl}$ flagellate $\mathrm{f}^{-1} \mathrm{~d}^{-1}$.

Estimates of $I$ from clearance rates and prey abundance ranged from 240 to 1420 bacteria flagellate $^{-1}$ $\mathrm{d}^{-1}$. Ingestion rates in Expt 1 were 902 bacteria flagellate $^{-1} \mathrm{~d}^{-1}$ (geometric mean). Ingestion rates were 453 and 308 bacteria flagellate ${ }^{-1} \mathrm{~d}^{-1}$ in Expts 2 and 3, respectively. Variations in ingestion rates for these experiments were heavily dependent upon prey abundance, given that the clearance estimates were essentially invariant. The value of $g$ ranged from 3 to 10.5 dance data were converted to biomass using the measured biovolumes, Stage 1 bacteria had a specific growth rate of $0.58 \mathrm{~d}^{-1}$, while essentially no growth was observed in Stage $2\left(-0.01 \mathrm{~d}^{-1}\right)$. Therefore, in terms of biomass-based estimates of specific growth rate, it appears that the Stage 1 bacteria were able to fully utilize the nitrogen in the medium, leaving none for growth in Stage 2.

In grazing Expt 1, Stage 1 bacterial biomass increased over the first week from 2.3 to $2.9 \mu \mathrm{g} \mathrm{C} \mathrm{ml}^{-1}$, then decreased steadily to $\sim 1 \mu \mathrm{gC} \mathrm{ml} \mathrm{m}^{-1}$ at Day 13 (Fig. 4). The medium was replenished with a new batch on Day 5, and it must have contained a lower concentration of available nitrogen in order to explain this trend. In Stage 2 of Expt 1, bacterial biomass fluctuated between 0.5 and $1 \mu \mathrm{g} \mathrm{C} \mathrm{ml}^{-1}$ throughout. For Expt 2, Stage 1 bacteria increased from $\sim 1 \mu \mathrm{g} \mathrm{C} \mathrm{ml}^{-1}$ to $1.5 \mu \mathrm{g} \mathrm{C} \mathrm{ml}^{-1}$ on Day 3 , then gradually decreased over the rest of the $16 \mathrm{~d}$ experiment to $1 \mu \mathrm{g} \mathrm{C} \mathrm{ml}^{-1}$ (Fig. 4). In Stage 2, biomass fluctuated between 0.1 and $0.6 \mu \mathrm{g} \mathrm{C}$ $\mathrm{ml}^{-1}$, with an average value of $\sim 0.5 \mu \mathrm{g} \mathrm{C} \mathrm{ml}^{-1}$. In Expt 3, Stage 1 bacterial biomass increased from 0.7 to $3 \mu \mathrm{g} \mathrm{C}$ $\mathrm{ml}^{-1}$ on Day 4, then decreased, presumably as a result of substrate limitation (Fig. 4). Stage 2 showed low and relatively constant biomass levels of 0.1 to $0.2 \mu \mathrm{gC}$ $\mathrm{ml}^{-1}$ over the entire experiment.

Stage 1 bacterial growth rates $\left(\mu_{1}\right)$ were always higher than Stage 2 net growth rates $\left(k_{2}\right)$, which is not surprising since net growth incorporates the grazing impact (Fig. 5). For all experiments, $\mu_{1}$ averaged $0.57 \pm$ $0.18 \mathrm{~d}^{-1}(\mathrm{n}=46)$, which was well-constrained by the di- 


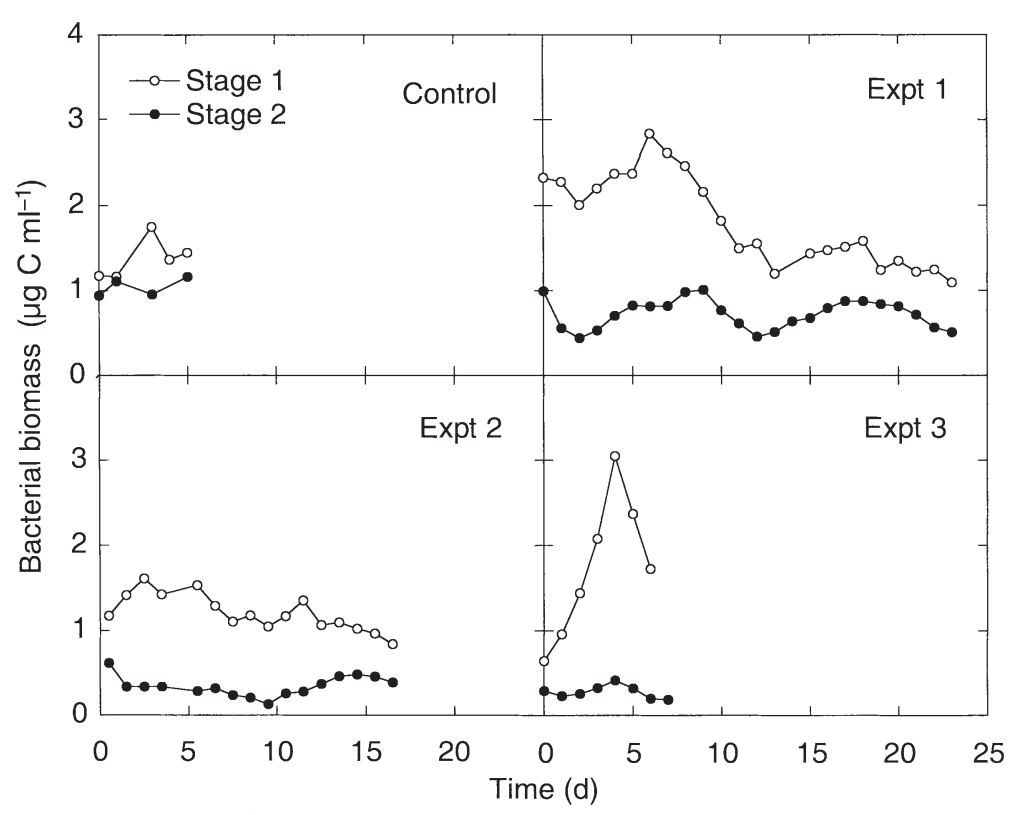

Fig. 4. Bacterial biomass $\left(\mu \mathrm{g} \mathrm{C} \mathrm{ml}^{-1}\right)$ in the control and grazing Expts 1 to 3 as a function of time. Bacterial biomass was estimated from bacterial abundance (see Fig. 1), biovolumes estimated experimentally (see 'Materials and methods: Biovolumes and biomass'), along with a carbon-

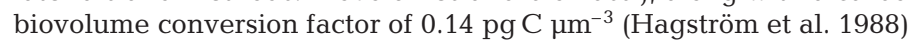

$\mathrm{d}^{-1}$ in Expt 3 (51, 43 and $114 \%$ coefficients of variation, respectively) (Fig. 6). The high variability of growth rate estimates may be somewhat artificial, due to random variability in the once-daily sampling estimates upon which they were based. If errors led to a significant underestimate of growth rate for a day, the estimates for the following day would likely compensate and be too high. In order to de-emphasize this possible artifact, the growth rate trend was calculated at $2 \mathrm{~d}$ intervals (Fig. 6, heavy lines on plots), which had the effect of damping variability (the coefficient of variation in all experiments dropped to $32-33 \%$ ). This procedure was especially valuable for the short Expt 3, where daily growth rates were alternately high then low. Even with this 2 d averaging, however, an apparent periodicity in growth rate of 3 to $4 \mathrm{~d}$ was evident in Expts 1 and 3, whereas the period was longer ( 6 to $7 \mathrm{~d}$ ) for Expt 2. These oscillations seemed to derive, at least in part, from fluctuations in bacterial abundance. lution rates of 0.5 to $0.6 \mathrm{~d}^{-1}$. In Stage 2 vessels, $k_{2}$ was negative throughout each experiment, averaging -1.46 $\pm 1.22 \mathrm{~d}^{-1}(\mathrm{n}=46)$, but varying in individual experiments from -4.55 to $0.01 \mathrm{~d}^{-1}$. Variability in the average growth rate, as measured by the coefficient of variation, was 2.7 times greater overall in Stage 2 than in Stage 1.

The combination of specific mortality estimates and net bacterial growth rates in the Stage 2 chemostats gave specific growth rates $\left(\mu_{2}=g+k_{2}\right)$ ranging from 0 to $10 \mathrm{~d}^{-1}$ (Fig. 5). In Expt 1, growth rates oscillated around $7 \mathrm{~d}^{-1}$ after the first week and averaged $6.3 \pm$ $1.7 \mathrm{~d}^{-1}$. In Expt 2, growth rates were near $7 \mathrm{~d}^{-1}$ during the first week, then steadily decreased to $\sim 2 \mathrm{~d}^{-1}$ by the end of the experiment (average of $4.6 \pm 1.9 \mathrm{~d}^{-1}$ ). Stage 2 growth rates also decreased steadily in Expt 3 over time, from $\sim 3$ to $1 \mathrm{~d}^{-1}$ after $5 \mathrm{~d}$ (average $1.8 \pm 0.8 \mathrm{~d}^{-1}$ ), and were essentially 0 for the last $2 \mathrm{~d}$. Compared to $\mu_{1}$, bacterial growth rates were up to 34-times higher in the presence of grazers, with average enhancements of 14-, 9-, and 2-fold in Expts 1 to 3, respectively.

Specific growth rates of flagellates in Expt 1 averaged $0.53 \pm 0.27 \mathrm{~d}^{-1}, 0.53 \pm 0.23 \mathrm{~d}^{-1}$ in Expt 2, and $0.44 \pm 0.50$

Fig. 5. Daily bacterial growth rates in grazing Expts 1 to 3 . Stage 1 bacterial gross growth rates $\left(\mu_{1}\right)$ are shown as solid bars, whereas Stage 2 gross growth rates $\left(\mu_{2}\right)$ are shown as open bars, and net bacterial growth rates $\left(k_{2}\right)$ are shown as shaded bars. These growth rates were calculated using Eqs. (3) \& (5), respectively (see text)

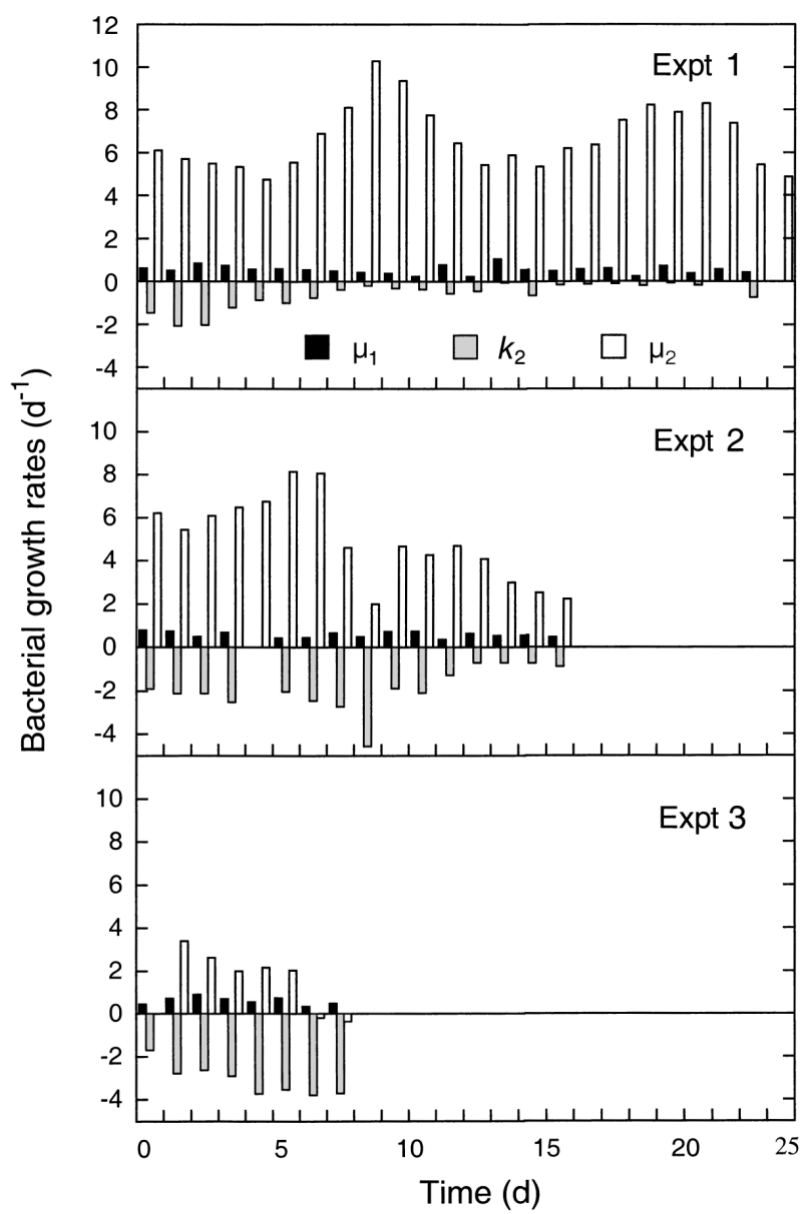




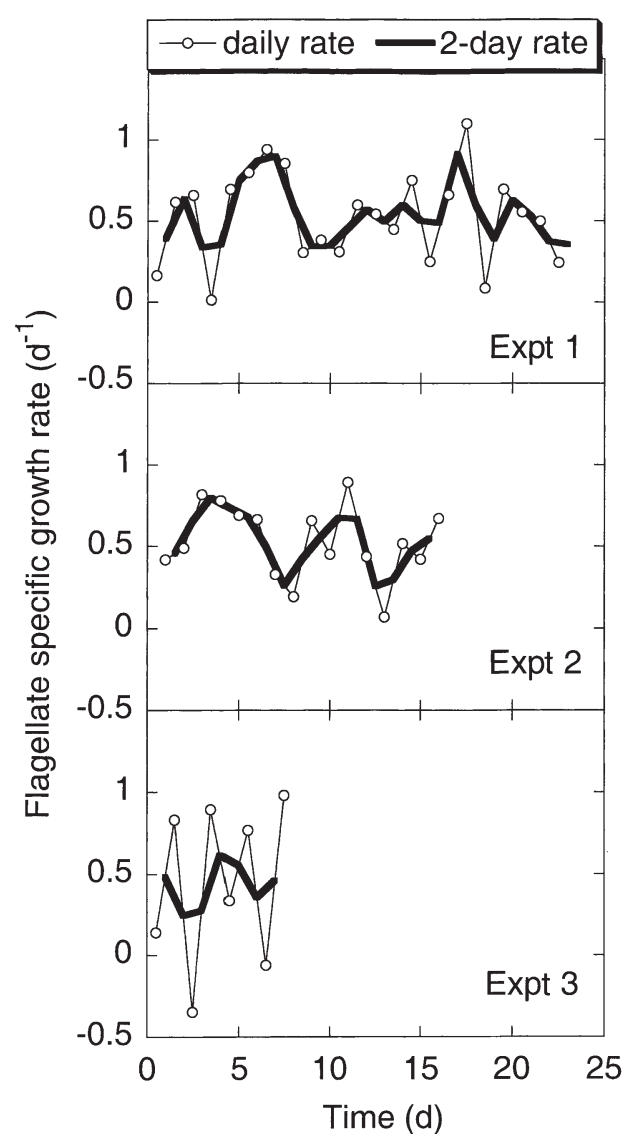

Fig. 6. Paraphysomonas bandaiensis. Flagellate specific growth rates $\left(\mathrm{d}^{-1}\right)$ in grazing Expts 1 to 3 as a function of time. Shown are daily rates (open circles) and $2 \mathrm{~d}$ rates (heavy solid line). These rates were calculated using Eq. (3)

\section{Flagellate gross growth efficiency}

Gross growth efficiencies (GGEs), determined from the daily carbon-based estimates of flagellate growth and bacteria ingested, averaged $28 \pm 26 \%$ over all experiments (Fig. 7). In Expt 1, the average GGE was $16 \pm 9 \%$. In Expts 2 and 3, the GGEs were higher overall (averages of $39 \%$ in Expt 2 and $41 \%$ in Expt 3). GGEs appeared to vary on 2 time scales. Short-term variability was evident, especially in Expt 3, where inaccuracies in estimating day-to-day flagellate abundance likely led to a coefficient of variation of $134 \%$. The $2 \mathrm{~d}$ average dampened variability (coefficient of variation $=45 \%$ ), while decreasing mean Expt 3 GGE to $30 \%$. Two day averaging had a less dramatic impact on Expts 1 and 2, reducing overall variability by only 12 to $18 \%$. The second time-scale of variability in these experiments was the 3 to $5 \mathrm{~d}$ oscillations of 15 to $30 \%$ in GGE, as seen in all experiments. These longer-term oscillations appeared to be more closely related to changes in flagellate growth rates, as opposed to ingestion estimates, but that may reflect the fact that the growth rates were more sensitive to random errors in measurement.

\section{Inferred nitrogen regeneration}

In our nitrogen-limited chemostats, positive bacterial growth in the second stage can only result if the bacteria in the first stage do not use all the growthlimiting substrate or if the flagellate remineralizes reduced nitrogen. In the control experiment, the firststage bacterial population completely used the available organic nitrogen, such that the second stage bacteria did not grow. Therefore, calculations were made to determine whether the inferred bacterial growth rates in the second stage were reasonable, based on the assumption that all such growth must depend upon regenerated nitrogen derived from flagellate grazing. With a few exceptions, the calculated regeneration of nitrogen by the flagellate balanced

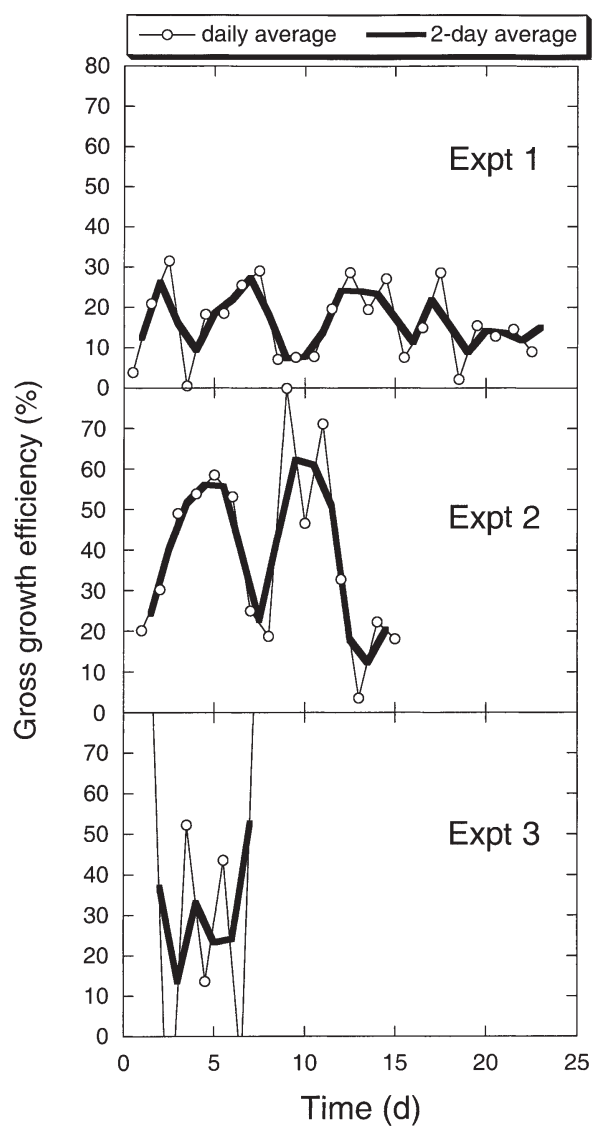

Fig. 7. Paraphysomonas bandaiensis. Gross growth efficiency (\%) as daily and $2 \mathrm{~d}$ averages during each of the grazing Expts 1 to 3 . The daily average is shown by the open circles, whereas the $2 \mathrm{~d}$ average is indicated by the heavy solid lines 


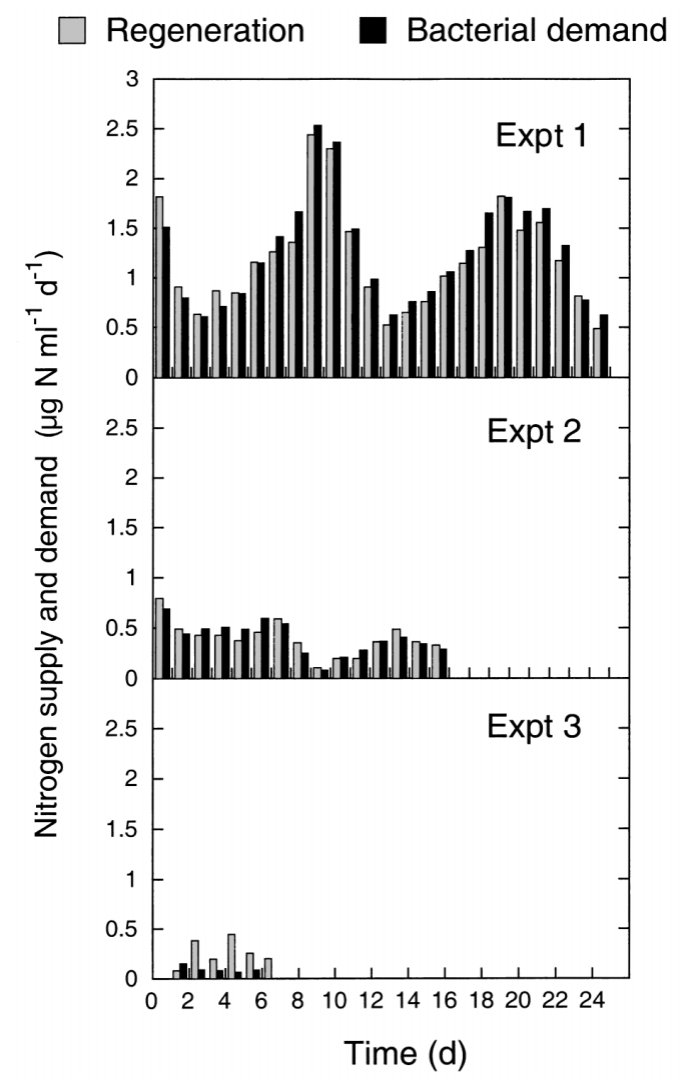

Fig. 8. Reduced nitrogen supply ('regeneration') and demand ('bacterial demand') as estimated in each of the grazing experiments

the bacterial population's nitrogen demand at the inferred rate of specific growth (Fig. 8). Regeneration of nitrogen by the flagellate ranged from 0.1 to $2.4 \mu \mathrm{g}$ $\mathrm{N} \mathrm{ml}^{-1} \mathrm{~d}^{-1}$ in the experiments. When calculated on a daily basis, regeneration exceeded demand for $\mathrm{N}$ $43 \%$ of the time, whereas regeneration was $>80 \%$ of demand on $86 \%$ of the days. The highest rates of regeneration and demand were in Expt 1, whereas the lowest rates were in Expt 3. Also, the imbalance between regeneration and demand was the greatest in Expt 3, with more inferred regeneration than apparent demand.

\section{DISCUSSION}

\section{Flagellate carbon and nitrogen content}

Biovolume-to-biomass conversion factors are critical for determining flagellate gross-growth efficiencies. In the present work, exponentially growing Paraphysomonas bandaiensis had a carbon-biovolume conversion factor of $0.13 \mathrm{pg} \mathrm{C} \mathrm{mm}^{-3}$. When the flagel- lates were glutaraldehyde-preserved, the conversion

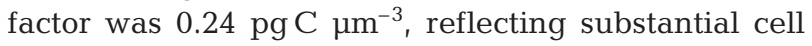
shrinkage upon preservation. Both are within the 3fold range of published estimates (0.10 to $0.30 \mathrm{pgC}$ $\mu \mathrm{m}^{-3}$ : Fenchel 1982b, Børsheim \& Bratbak 1987, Verity et al. 1992, Eccleston-Parry \& Leadbeater 1995). Of these published estimates, the only conversion factor based on the biovolumes of live heterotrophic

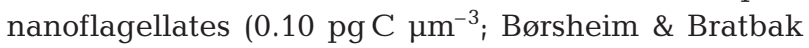
1987 ) is quite compable to what we found here. Verity et al. (1992) derived a live biovolume conversion

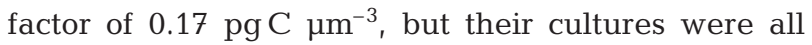
algal cells, which may not be directly comparable because of their different cellular organelles and metabolic needs.

The carbon:nitrogen (w:w) ratio of Paraphysomonas bandaiensis was 5.2 when fed heterotrophic bacteria. This ratio is quite similar to those published by Eccleston-Parry \& Leadbeater (1995) for 4 bacterivorous species of nanoflagellates (C:N ranging from 4.1 to 5.5), and for the Monas sp. ( $\mathrm{C}: \mathrm{N}=4.6)$ studied by Børsheim \& Bratbak (1987). The elemental ratios of grazers and prey exert a strong influence on the fraction of ingested material remineralized (e.g. Caron et al. 1990, Landry 1993). In the present experiments, we assumed a bacterial C:N ratio of 4 . However, even with ratios as high as those reported by Fukuda et al. (1998), 5.8 and 5, respectively, for oceanic and coastal bacteria, calculated flagellate nitrogen regeneration would still have been sufficient to support the bulk $(89 \pm 14 \%$, $\mathrm{n}=26$ ) of bacterial $\mathrm{N}$ demand.

\section{Flagellate GGE}

Since protists appear to have a relatively low basal metabolism (i.e. the energy required for basic life processes is negligible compared to that for food processing and growth, Fenchel \& Finlay 1983, Fenchel 1987), growth rates should be proportional, in theory, to ingestion rates. Therefore, when populations are cultured under balanced conditions (i.e. growing exponentially, all chemical pools turning over at constant rates), the ratio of growth to ingestion (GGE) should be constant. In practice, GGEs for many protists do seem to vary considerably - even within the same species and despite efforts to conduct balanced-growth experiments (e.g. Verity 1985, Strom \& Busky 1993, Peters et al. 1996). Thus, other factors, such as food concentration or quality, apparently influence GGE. In the present chemostat experiments, flagellate GGE estimates varied substantially, with a standard deviation as great as the mean $(28 \pm 26 \%$, $\mathrm{n}=53$ ). The average estimate is at the low end of the range for GGEs of bacterivorous flagellates (27 to 
45\%: Fenchel 1982b, Sherr et al. 1983, Caron et al. 1985, Goldman \& Caron 1985, Goldman et al. 1985, Andersen et al. 1986, Fenchel 1988, Geider \& Leadbeater 1988, Caron et al. 1990), but close to the overall average for flagellates as reported by Straile (1997). Food concentrations in the present experiments were sufficient to support only modest rates of flagellate growth; thus, the GGEs would not be expected to be as high as they would be if food were present at or above levels supporting maximal growth. Another complicating factor in the present experiments is that day-to-day variations in bacterial size and species composition were not monitored; thus, their influences on GGE could not be evaluated.

The longer 3 to $5 \mathrm{~d}$ variations in GGE estimates found here could be due to variable food quality as the prey became nitrogen-limited, decreasing the food value of individual cells. However, there is evidence to suggest that carbon-based GGEs do not change appreciably when prey are nitrogen-limited (Caron et al. 1990). Peters et al.'s (1996) study of the effects of turbulence on ingestion rates of Paraphysomonas imperforata showed highly variable GGEs (averages ranging from 12 to $32 \%$ ) in replicate treatments, even under control conditions without turbulence, and despite efforts to conduct the experiments with the flagellates in the same growth state and prey abundance. Straile (1997) showed that variations in GGE were most often correlated with changes in food concentration. In the present experiments, the longer term fluctuations in GGE were on the same time scale as changes in flagellate growth rate. Thus, it is possible that the flagellates respond to changes in food availability by changing their physiology in some way, perhaps by adjusting digestive enzymes. Alternatively, the growth rate variations reflected more subtle responses of feeding rates to changes in unmeasured properties of the bacterial prey.

One implication of this work involves the time scales of predator adaptation to new growth conditions. Many laboratory studies of flagellates use experimental conditions different from the conditions under which the flagellates have been grown. At least for flagellates growing at rates well below their maximum potential, several generations may be needed to adapt to a new medium. In Expt 1, for instance, the flagellates were growing, on average, at the dilution rate of $0.5 \mathrm{~d}^{-1}$, yet it took $4 \mathrm{~d}(\sim 3$ cell doublings $)$ for their biovolumes to stabilize and for growth to occur in the presence of high food. Therefore, pre-adaption to experimental conditions is essential for avoiding non-transient growth responses during short-term experiments. Chemostat cultures are ideal for this, since the rate of supply of growth medium can be regulated.

\section{Consequences of remineralization}

While many investigators have acknowledged the contribution of protists to remineralization, relatively few have estimated the magnitude of grazer-enhanced prey growth rates. Of those few, Šimek et al. (1997) took an approach very similar to that of this study. They grew protistan predators in 2-stage continuous cultures and measured grazing rates at intervals. From this, they estimated prey-enhanced growth rates of 4 to $8 \mathrm{~d}^{-1}$, much higher than the dilution rate of the system $\left(0.25 \mathrm{~d}^{-1}\right)$. Another example is the batch culture work of Synder \& Hoch (1996), where flagellate predators feeding on bacterial prey were incubated with ${ }^{3} \mathrm{H}$-thymidine. They found that bacterial production rates were enhanced 2- to 3-fold in the presence of grazers relative to controls. Similarly, Šolić \& Krstulović (1994) found enhanced bacterial growth rates using radiotracers in a grazing system. Güde (1985) grew Chlorella sp. with and without bacteria in the first of a 2-stage chemostat and a mixed population of protistan predators in the second, finding that $\mathrm{P}, \mathrm{N}$ and $\mathrm{C}$ remineralization were several-fold higher in the presence of the grazer. Since the Güde (1985) study did not include grazing rate estimates, however, the magnitude of prey growth stimulation could not be estimated. Habte \& Alexander (1978) observed that the bacteria Escherichia coli and Klebsiella pneumoniae maintained high densities of 1 and $5 \times 10^{6}$ cells ml ${ }^{-1}$, respectively, in batch cultures grazed by Tetrahymena pyriformis. However, in the presence of the bacterial growth inhibitor chloroamphenicol, bacterial standing stocks decreased dramatically, to $<600$ cells $\mathrm{ml}^{-1}$, due to T. pyriformis grazing. This demonstrated that growth of the bacteria was responsible for their persistence in the presence of grazers, but since neither grazing nor growth rates were measured, the magnitude of the bacterial growth enhancement was unconstrained.

In the present study, we found bacterial growth rates 2- to 14-fold higher in the presence of flagellate predators than in their absence. The evidence for enhanced bacterial growth rates comes from examination of the grazers' growth and grazing rates, independent measurements that lead to internally consistent constraints on the rates of bacterial growth and nutrient flux.

Flagellate growth rates are constrained by the chemostat dilution rate, at which the population must grow to escape wash-out. Actual growth rates were determined using daily estimates of abundance and biovolume. Although the flagellate turnover rates were modest, the population density was quite high. Very high growth rates were therefore needed by the bacteria in Stage 2 vessels to account for the high rates of flagellate biomass production. Independently, we are led to this same conclusion based on experimental estimates of flagellate 
grazing impact using fluorescent tracers. Stage 2 bacterial growth must be sufficient to balance grazing loss rates of 2 to $10 \mathrm{~d}^{-1}$, as well as chemostat dilution.

From these independent lines of evidence, bacterial growth rates were significantly and unambiguously enhanced over controls. Indeed, the assumption of no bacterial growth would imply impossibly high estimates of flagellate gross growth efficiency (i.e. $>100 \%$ ). Presumably, bacterial growth occurred through remineralized ammonia or other reduced nitrogen-containing compounds since an excess of organic carbon substrates were added to the medium ( $\mathrm{C}: \mathrm{N}=14$ vs bacterial $\mathrm{C}: \mathrm{N} \sim 4$ to 6.8 ), whereas nitrogen was added in a limited quantity. From the elemental ratios of predator and prey, growth and grazing estimates, and mass balance calculations, nitrogen regeneration appeared to be sufficient to support high bacterial nitrogen demand consistent with high growth rates. The mass balance calculation also demonstrates the extraordinarily tight coupling of flagellate remineralization and bacterial growth rates.

If viral lysis was a significant process in these experiments, then it could have lead to remineralization through the bursting of cells and subsequent release of their organic contents. In that case, protistan grazing would not be the only pathway leading to remineralization, but the viral products would presumably require secondary processing before becoming utilizable for bacterial growth. In addition, if significant numbers of bacteria were lost to cell lysis, they could not simultaneously be available for flagellate consumption. Thus, at the measured levels of protistan production, the bacterial prey would have had to grow even faster than estimated to account for significant losses to viruses. These system mass-balance constraints make it unlikely that viral infection and lysis contributed significantly to the general results from these experiments.

Natural oceanic bacteria are likely to be growth-rate limited by the availability of utilizable reduced carbon substrates, and thus would not necessarily display the very high rates we found in our nitrogen-limited, but carbon-sufficient, chemostats. Nevertheless, the central conclusions of this study regarding predator adaptations to food supply, stoichiometric-based regeneration of excess nutrients and utilizable by-products of grazing should still apply, just not to the magnitude seen in these experiments.

\section{Inferences from cultured versus natural food web interactions}

Although culture experiments are repeatedly and regularly used as models of how natural systems might operate, both the conditions and the organisms themselves differ appreciably from those in nature. For example, many years of living under culture conditions by our experimental flagellate, Paraphysomonas bandaiensis, may have selected for characteristics that bear little resemblance to the same species in the wild. Even the bacterial prey, although initially representative of a natural assemblage, had an evolving phylogenetic signature (as evinced by right angle light scatter and DNA fluorescence measured by flow cytometry) as they responded to the imposed nutrient regime and grazing pressure (data not shown).

Despite these caveats, as well as the highly concentrated conditions and simple trophic structure of our experiments, several general observations can be made. The simple chemostat-grown food web examined in this work showed oscillations over time, not unlike those found in real world scenarios. For instance, Calbet \& Landry (2001) observed that microbial community interactions at an oligotrophic openocean site were quite variable over time, suggesting regular oscillations between resource and predator controls. In the present experiments, the dynamics of predator-prey oscillations in the second-stage chemostat chambers necessitate non steady-state mathematical descriptions. Although these suggest slightly different time-scales for the coupled processes of growth, grazing and remineralization, the overall sense is of a highly efficient coupling of fluxes through the various nitrogen pools. Bacteria take up the dissolved organic substrate, grow and are consumed. There is likely a lag between protist consumption and subsequent egestion and excretion of remineralized products. Nonetheless, even in a relatively nutrient-rich culture system, the limiting nutrient is remineralized efficiently according to the stoichiometric difference between the protistan consumers and their prey. Furthermore, given mass balance and the daily scale of culture chamber washout, the protist-derived remineralized nutrient, now in inorganic form, appears to be utilized quantitatively and almost immediately for cell growth in the bacterial consortium.

The tight coupling of these feedback processes have become an accepted cliché over the past 2 decades of research on the 'microbial loop'. Yet unless they all occur at precisely the same rates, oscillations in predator and prey populations should occur in the absence of external stabilizing forces. The rate-limiting step in this coupled flux system is not known, but it could be the rate at which the grazer can process ingested food from the particulate to the dissolved state, along with how that rate is effected by changes in prey quantity and quality. As an indication of this processing time, the flagellates in the present experiments adjusted their cell-specific biomass over several days under the 
imposed conditions of growth rate (governed by the chemostat dilution factor) and prey concentration. As suggested above, the relatively rapid and quantitative recovery of excreted nutrients as bacterial growth make it unlikely that the rate-limiting step is bacterial uptake of the limiting substrate.

In this simple food chain, the grazers were limited by particulate carbon. Despite their high biomass, a function of the high concentrations of available food, they were individually functioning at growth rates not atypical of flagellates in the open ocean (Landry et al. 2000, 2003). If the chemostat system had been strongly carbonlimited, we might have observed bacteria closer to natural abundances, with the lower standing stocks providing less food for the flagellates. This would have depressed grazer densities substantially, but it is unclear whether individual flagellate size would have also adjusted, unless the bacteria themselves were also smaller. This presumes, of course, that more realistic oceanic concentrations of bacterial prey would have been sufficient to support flagellate growth rates equal to those of chemostat dilution, which seems unlikely given the general coastal habitat of Paraphysomonas bandaiensis and the culture history of clone used. Although we might expect that nitrogen remineralization in a carbon-limited system would be even more efficient than observed here, since it derives from the stoichiometric differences between food sources and grazer growth requirements, the subsequent step of bacterial uptake for growth would be inefficient, since nitrogen would already be available in excess relative to carbon.

Most of the bacterial population decrease in the present experiments involved a simple transfer of carbon to the flagellates. Since prey carbon is not converted to predator carbon with $100 \%$ efficiency, however, the overall rate of carbon mineralization of a predator-containing system is higher than without predators. Respired carbon $\left(\mathrm{CO}_{2}\right)$ is unavailable to heterotrophs (by definition), but at least a portion of the egested organic carbon would presumably be utilizable by heterotrophic bacteria. Thus, in a simple bacteria-grazer, carbon-limited system, without any additional sources of fixed carbon by primary producers, the magnitude of the grazer stimulation of bacterial growth rate would likely reflect only the amount of labile DOC released by the grazers.

\section{CONCLUSIONS}

Elemental balance constraints on the grazing and growth of heterotrophic flagellates in the present 2 -stage chemostat experiments show clear and substantial enhancement of bacterial growth rates by grazing and nutrient remineralization processes.
Bacterial growth and grazing-loss rates cannot simply be calculated from abundance differences in sequential stages of a chemostat without accounting for such feedbacks. Although the nutrient concentrations and population densities in the present experiments greatly exceeded those in open-ocean, and indeed most coastal ecosystems, the concept of closely coupled production, grazing and remineralization processes applies broadly to microbe-dominated systems (e.g, Azam et al. 1983, Landry et al. 1997). It is worth noting that even within bacterial populations derived from a natural bacterial assemblage enriched from subtropical oligotrophic waters, at least some populations can achieve extraordinary growth rates $(2 \mathrm{~h}$ doubling times) when the conditions allow. With virtually no constraint on growth potential, the realized abundance levels and turnover rates of bacteria in natural ecosystems clearly reflect a highly honed balance of substrate supply and grazer removal processes.

Acknowledgements. The authors thank Hector Nolla for his invaluable flow cytometry expertise and David Hashimoto for carbon-nitrogen analysis assistance. This research was supported by National Science Foundation Grants OCE-9218152 and OCE-9315432 to MRL. This is contribution no. 6144 from the School of Ocean and Earth Science and Technology, University of Hawaii at Manoa.

\section{LITERATURE CITED}

Andersson A, Larsson U, Hagström Å (1986) Size selective grazing by a microflagellate on pelagic bacteria. Mar Ecol Prog Ser 33:51-57

Ashby RE (1976) Long term variations in a protozoan chemostat culture. J Exp Mar Biol Ecol 24:227-235

Azam F, Fenchel T, Field JG, Gray JS, Meyer-Reil LA, Thingstad F (1983) The ecological role of water-column microbes in the sea. Mar Ecol Prog Ser 10:257-263

Berninger UG, Caron DA, Sanders RW, Finlay BJ (1991) Heterotrophic flagellates of planktonic communities, their characteristics and methods of study. In: Patterson DJ, Larsen J (eds) The biology of free-living heterotrophic flagellates. Systematics Association, Clarendon Press, Oxford, Special Vol 45, p 39-56

Børsheim KY, Bratbak G (1987) Cell volume to cell carbon conversion factors for a bacterivorous Monas sp. enriched from seawater. Mar Ecol Prog Ser 36:171-175

Calbet A, Landry MR (1999) Mesozooplankton influences on the microbial food web: direct and indirect trophic interactions in the oligotrophic ocean. Limnol Oceanogr 44: $1370-1380$

Calbet A, Landry MR (2001) Bacteria-flagellate interactions in the microbial food web of the oligotrophic subtropical North Pacific. Aquat Microb Ecol 23:283-292

Caron DA, Goldman JC, Andersen OK, Dennett MR (1985) Nutrient cycling in a microflagellate food chain. II. Population dynamics and carbon cycling. Mar Ecol Prog Ser 24: $243-254$

Caron DA, Goldman JC, Dennett MR (1990) Carbon utilization by the omnivorous flagellate Paraphysomonas imperforata. Limnol Oceanogr 35:192-201 
Cotner JB, Ammerman JW, Peele ER, Bentzen E (1997) Phosporus-limited bacterioplankton growth in the Sargasso Sea. Aquat Microb Ecol 13:141-149

Curds CR, Cockburn A (1971) Continuous monoxenic culture of Tetrahymena pyriformis. J Gen Microbiol 66:95-108

Eccleston-Parry JD, Leadbeater BSC (1994a) A comparison of the growth kinetics of 6 marine heterotrophic nanoflagellates fed with one bacterial species. Mar Ecol Prog Ser 105:167-177

Eccleston-Parry JD, Leadbeater BSC (1994b) The effect of long-term low bacterial density on the growth kinetics of three marine heterotrophic nanoflagellates. J Exp Mar Biol Ecol 177:219-233

Eccleston-Parry JD, Leadbeater BSC (1995) Regeneration of phosphorus and nitrogen by four species of heterotrophic nanoflagellates feeding on three nutritional states of a single bacterial strain. Appl Environ Microb 61:1033-1038

Elser JJ, Urabe J (1999) The stoichiometry of consumer-driven nutrient recycling: theory, observations, and consequences. Ecology 80:735-751

Fagerbakke KM, Heldal M, Norland S (1996) Content of carbon, nitrogen, oxygen, sulfur and phosphorus in native aquatic and cultured bacteria. Aquat Microb Ecol 10: $15-27$

Fenchel T (1982a) Ecology of heterotrophic microflagellates. II. Bioenergetics and growth. Mar Ecol Prog Ser 8:225-231

Fenchel T (1982b) Ecology of heterotrophic microflagellates. IV. Quantitative occurrence and importance as bacterial consumers. Mar Ecol Prog Ser 9:35-42

Fenchel T (1987) Ecology of protozoa. Science Tech, Madison

Fenchel T (1988) Marine plankton food chains. Annu Rev Ecol Syst 19:19-38

Fenchel T, Finlay BJ (1983) Respiration rates in heterotrophic, free-living protozoa. Microb Ecol 9:99-122

Fogg AG (1986) Picoplankton. Proc R Soc Lond B 228:1-30

Frost BW (1972) Effects of size and concentration of food particles on the feeding behavior of the marine planktonic copepod Calanus pacificus. Limnol Oceanogr 27:805-810

Fukuda R, Ogawa H, Nagata T, Koike I (1998) Direct determination of carbon and nitrogen contents of natural bacterial assemblages in marine environments. Appl Environ Microbiol 64:3352-3358

Geider RJ, Leadbeater BSC (1988) Kinetics and energetics of growth of the marine choanoflagellate Stephanoeca diplocostata. Mar Ecol Prog Ser 47:169-177

Goldman JC, Caron DA (1985) Experimental studies on an omnivorous microflagellate: implications for grazing and nutrient regeneration in the marine microbial food chain. Deep-Sea Res 32:899-915

Goldman JC, Caron DA, Andersen OK, Dennett MR (1985) Nutrient cycling in a microflagellate food chain. I. Nitrogen dynamics. Mar Ecol Prog Ser 24:231-242

Güde H (1985) Influence of phagotrophic processes on the regeneration of nutrients in two-stage continuous culture systems. Microb Ecol 11:193-204

Guillard RRL, Ryther JH (1962) Studies of marine planktonic diatoms. I. Cyclotella nana Hustedt and Detonula confervacea (Cleve) Gran. Can J Microbiol 8:229-239

Habte M, Alexander M (1978) Mechanisms of persistence of low numbers of bacteria preyed upon by protozoa. Soil Biol Biochem 10:1-6

Hagström ^̊, Azam F, Andersson A, Wikner J, Rassoulzadegan F (1988) Microbial loop in an oligotrophic pelagic marine ecosystem: possible roles of cyanobacteria and nanoflagellates in the organic fluxes. Mar Ecol Prog Ser 49:171-178

Hahn MW, Höfle MG (1998) Grazing pressure by a bacterivo- rous flagellate reverses the relative abundance of Comamonas acidovorans PX54 and Vibrio strain CB5 in chemostat cultures. Appl Environ Microbiol 64:1910-1918

Hamilton R, Preslan J (1970) Observations on continuous cultures of a planktonic phagotrophic protozoan. J Exp Mar Biol Ecol 5:94-104

Hoch MP, Snyder RA, Cifuentes LA, Coffin RB (1996) Stable isotope dynamics of nitrogen recycled during interactions among marine bacteria and protists. Mar Ecol Prog Ser 132:229-239

Jost JL, Drake JF, Fredrickson AG, Tsuchiya HM (1973) Interactions of Tetrahymena pyriformis, Escherichia coli, Azotobacter vinelandii, and glucose in a minimal medium. J Bacteriol 113:834-840

Jürgens K, Güde H (1990) Incorporation and release of phosphorus by planktonic bacteria and phagotrophic flagellates. Mar Ecol Prog Ser 59:271-284

Karl DM (1999) A sea of change: biogeochemical variability in the North Pacific subtropical gyre. Ecosystems 2:181-214

Kuipers B, van Noort GJ, Vosjan J, Herndl GJ (2000) Diel periodicity of bacterioplankton in the euphotic zone of the subtropical Atlantic Ocean. Mar Ecol Prog Ser 201:13-25

Landry MR (1993) Predicting excretion rates of microzooplankton from carbon metabolism and elemental ratios. Limnol Oceanogr 38:468-472

Landry MR, Kirchman DL (2002) Microbial community structure and variability in the tropical Pacific. Deep-Sea Res II 49:2669-2693

Landry MR, Barber RT, Bidigare RR, Chai F and 9 others (1997) Iron and grazing constraints on primary production in the central equatorial Pacific: an EqPac synthesis. Limnol Oceanogr 42:405-418

Landry MR, Constantinou J, Latasa M, Brown SL, Bidigare RR, Ondrusek ME (2000) Biological response to iron fertilization in the eastern equatorial Pacific (IronEx II). III. Dynamics of phytoplankton growth and microzooplankton grazing. Mar Ecol Prog Ser 201:57-72

Landry MR, Brown SL, Neveux J, Dupouy C, Blanchot J, Christensen S, Bidigare RR (2003) Phytoplankton growth and microzooplankton grazing in HNLC waters of the equatorial Pacific: community and taxa-specific rate assessments from pigment and flow cytometric analyses. J Geophys Res (in press)

Lee S, Fuhrman JA (1987) Relationships between biovolume and biomass of naturally derived marine bacterioplankton. Appl Environ Microbiol 53:1298-1303

Monger BC, Landry MR (1990) Direct-interception feeding by marine zooflagellates: the importance of surface and hydrodynamic forces. Mar Ecol Prog Ser 65:123-140

Monger BC, Landry MR (1991) Prey-size dependency of grazing by free-living marine flagellates. Mar Ecol Prog Ser 74: $239-248$

Monger BC, Landry MR (1992) Size-selective grazing by heterotrophic nanoflagellates: an analysis using live-stained bacteria and dual-beam flow cytometry. Arch Hydrobiol Beih 37:173-185

Monger BC, Landry MR (1993) Flow cytometric analysis of marine bacteria with Hoechst 33342. Appl Environ Microbiol 59:905-911

Parslow JS, Doucette GJ, Taylor FJR, Harrison PJ (1986) Feeding by the zooplankton Pseudobodo sp. on the picoplanktonic prasinomonad Micromonas pusilla. Mar Ecol Prog Ser 29:237-246

Pengerud B, Skjoldal EF, Thingstad TF (1987) The reciprocal interaction between degradation of glucose and ecosystem structure. Studies in mixed chemostat cultures of marine bacteria, algae, and bacterivorous nanoflagellates. 
Mar Ecol Prog Ser 35:111-117

Pernthaler J, Posch T, Šimek K, Vrba J, Amann R, Psenner R (1997) Contrasting bacterial strategies to coexist with a flagellate predator in an experimental microbial assemblage. Appl Environ Microbiol 63:596-601

Peters F, Choi JW, Gross T (1996) Paraphysomonas imperforata (Protista, Chrysomonadida) under different turbulence levels: feeding, physiology and energetics. Mar Ecol Prog Ser 134:235-245

Rivkin RB, Anderson MR (1997) Inorganic nutrient limitation of oceanic bacterioplankton. Limnol Oceanogr 42:730-740

Sambanis A, Fredrickson AG (1987) Long-term studies of ciliate-bacterial interactions: use of a chemostat fed with bacteria grown in a separate chemostat. J Gen Microbiol 133:1619-1630

Sherr BF, Sherr EV, Berman T (1983) Grazing, growth, and ammonium excretion rates of a heterotrophic microflagellate fed with four species of bacteria. Appl Environ Microbiol 45:1196-1201

Sherr BF, Sherr EB, Fallon RD (1987) Use of monodispersed, fluorescently labeled bacteria to estimate in situ protozoan bacterivory. Appl Environ Microbiol 53:958-965

Šimek K, Vrba J, Pernthaler J, Posch T, Hartman P, Nedoma J, Psenner R (1997) Morphological and compositional shifts in an experimental bacterial community influenced by protists with contrasting feeding modes. Appl Environ Microbiol 63:587-595

Snyder RA, Hoch MP (1996) Consequences of protist-stimulated bacterial production for estimating protist growth

Editorial responsibility: Fereidoun Rassoulzadegan, Villefranche-sur-Mer, France efficiencies. Hydrobiol 341:113-123

Šolić M, Krstulović N (1994) Role of predation in controlling bacterial and heterotrophic nanoflagellate standing stocks in the coastal Adriatic Sea: seasonal patterns. Mar Ecol Prog Ser 114:219-235

Straile D (1997) Gross growth efficiencies of protozoan and metazoan zooplankton and their dependence on food concentration, predator-prey weight ratio, and taxonomic group. Limnol Oceanogr 42:1375-1385

Strom SL, Busky EJ (1993) Feeding, growth, and behavior of the thecate heterotrophic dinoflagellate Oblea rotunda. Limnol Oceanogr 38:965-977

Swift ST, Najita IY, Ohtaguchi K, Fredrickson AG (1982) Some physiological aspects of the autecology of the suspension-feeding protozoan Tetrahymena pyriformis. Microb Ecol 8:201-215

Thingstad TF (1987) Utilization of N, P, and organic C by heterotrophic bacteria. I. Outline of a chemostat theory with a consistent concept of 'maintenance' metabolism. Mar Ecol Prog Ser 35:99-109

Vaulot D (1989) CYTOPC: processing software for flow cytometric data. Signal to Noise 2:8

Verity PG (1985) Grazing, respiration, excretion, and growth rates of tintinnids. Limnol Oceanogr 30:1268-1282

Verity PG, Robertson CY, Tronzo CR, Andrews MG, Nelson JR, Sieracki ME (1992) Relationships between cell volume and the carbon and nitrogen content of marine photosynthetic nanoplankton. Limnol Oceanogr 37: $1434-1446$

Submitted: June 18, 2001; Accepted: January 13, 2003

Proofs received from author(s): April 11, 2003 